\title{
Managing University Finances for Sustainable Administration and Institution-Building
}

\author{
Babatunde Joel Todowede
}

\author{
Lagos State University \\ Badagry Expressway \\ P.M.B. 0001, Lagos, Nigeria
}

Doi:10.5901/jesr.2013.v3n4p97

\begin{abstract}
This paper, entitled "Managing University Finances for Sustainable Administration and InstitutionBuilding", seeks to demonstrate the possible application of sound financial management techniques for the attainment of enduring employment relationships and sustainable university governance. It should be recognized that employment relationships in the university system could be very complex, involving often delicate diversities, several competing multilateral interests and decision processes. Consequently, positive university governance should leverage strategic financial management approaches for the effective and efficient utilization of financial resources that are available in meeting the demands of their founding objectives.
\end{abstract}

\section{Introduction}

The structure of this paper is broken into some six broad parts for ease of presentation. Background information is initially provided on the societal role of education and social capacity building, while some key associated underlying concepts (e.g. financial management, financial planning, and financial accountability) are explained. Thereafter, the issue of University funding and finances is discussed. The variables that influence availability and management of university funds are further elaborated, with a particular emphasis on the imperative of strategic financial management for probable sustainable futures of university governance and institution-building. The paper concludes that the future of the university system, especially in an emerging nation such as Nigeria, lies in the embrace of best practices of university governance, including sound resource management, financial accountability and reporting as well as initiatives in favour of strategic capacity building for symmetrical organization development in line with the founding objectives.

\section{Conceptual Framework of Thought}

Education is regarded as the singular most important instrument for holistic human development and the empowerment of citizens of any nation. The global perception agrees that for economic and social development to be derived effectively there is a need for advancement in, and application of knowledge (Adebayo, Oyenike and Adesoji, 2007). It is evident that illiteracy, or the lack of formal education, often constrains the logical process of human development in any nation. Given the importance of human capital and its harnessing for economic growth and sustainable development, widespread or free education is often a desirable ideal. However, depending on a country's economic endowment or financial resources, and the existence of various competing demands of public expenditure in the social sector, the financing of free or widespread education may be problematic and unaffordable or uneconomical. However, with the effective and efficient management of a nation's resources (human, material or physical/natural and financial), 
organizations therein, including universities, can very well sustain their existence, operations and growth.

Financial management means planning, organising, directing and controlling the financial activities such as procurement and utilization of funds of the Institution. In other words, financial management is the management of the finances of a business/organization in order to achieve financial objectives. In general terms, it means applying general management principles to catalysing and sustaining the financial resources of the Institution.

Financial management includes (16financialmanagement, 2006);

- Financial planning and budgeting,

- Financial accounting,

- Financial analysis,

- Financial decision-making and

- Action.

Financial planning is about (16financialmanagement, 2006);

- Making sure that the organization can survive,

- Making sure the money is being spent in the most efficient way,

- Making sure that the money is being spent to fulfil the objectives of the organization,

- $\quad$ Being able to plan for the future of the organization in a realistic way.

Financial Accountability: In non-profit organizations, whatever money is available for expenditure only is meant to be held in trust - on behalf of the affected community that is being served. The money is not the personal possession of any organisation or person. Financial managers, therefore, have to account for the ways and means by which such money may be used as well as particularly justify such usage with interest of public good.

However, financial accountability can be broken down into two components (16financialmanagement, 2006):

(a) Financial Accountability in terms of being able to account for the way the money is spent to:

- Donors,

- Boards and committees,

- Members, and

- The people whom the money is meant to benefit.

(b) Financial Responsibility, on the other hand, involves the following:

- Not taking on obligations the organization cannot meet,

- Paying staff and accounts on time,

- Keeping proper records of the money that comes into the organization and goes out of the organization.

\section{Objectives of Financial management:}

The primary purpose of financial management is to do with procurement, allocation and control of financial resources of a concern. The objectives of financial management specifically encompass the following (Ishola, 2008\};

- To ensure regular and adequate supply of funds to the concern,

- To ensure optimum funds utilization. Once the funds are received they should be utilised in maximum possible way,

- To ensure safety on investment. This implied that funds should be invested in safe ventures so that adequate rate of return can be achieved,

- Overall control of the Institution's resources;

- Guidance to all departments in all financial matters, particularly as regards the preparation and monitoring of their budgets; 
- The Institution's accounting, reporting and internal control procedures;

- Maintaining the financial information system;

- Administering the pay-roll, loan and pension schemes;

- Arranging adequate insurance cover for the University's assets;

- Ensuring that surplus funds are invested and managed prudently.

\section{Financial resources available to the Universities:}

Financing higher education in Nigeria in the present is a crucial national problem. The political, social and economic factors, which are currently having significant impact on the world economy, have necessitated the need to diversify the resources of education funding, mainly because reliance on only one source of revenue can inhibit educational growth. There are however some possible options of financing higher education (Omolade, 2008):

- $\quad$ Fund from owner government, popularly known as subvention,

- Tuition and fees,

- Gifts, Grants and Endowments,

- Investment income,

- Auxiliaries (Enterprises, Licenses, Parents and Alumni Association)

- Consultancies and Research activities,

- Community Participation,

- Scholarship/Bursary Scheme,

- Loan Scheme, etc.

The existing circumstances in the country and the attendant financial constraints have made education to suffer. Government is unable to ideally fund higher education effectively and efficiently due to lack of accurate baseline statistics the asymmetrical planning and prevalent economic crises. To sustain higher education in the country, all stakeholders must become involved in the financing, parents and guardian, the society in general, the private sector and nongovernmental agencies. The education sector can only approach the optimal in provision and production when every stakeholder strives to do its part on the financing of higher education in Nigeria.

This paper, therefore, also isolates six critical factors that tend to influence new trends in the funding of Universities in Nigeria. These are ( Erinosho, 2004):

- Massive expansion in University Education;

- Inability of the Country to finance this massive expansion, leading to the emergence of the private sector;

- The rationale for cost-sharing with parents and students;

- The public call for accountability and value for money;

- The emergence of foreign providers through the General Agreement on Trade in services (GATS);

- $\quad$ And, finally, the need for adjustment in Country funding to reduce widening disparity.

\section{Financial operations of Universities}

It should be noted that there have been major recent changes in the financial operations of universities in many countries. This change is as a result of diminishing public resources with the resultant effect, in most cases, of financial constraints within the university system. This situation has led to pressure from the government, and from within the university system itself, for a diversification of sources of financial support to the University which must also be backed by effective resource management. From the above observations and scenarios, it is clear that the University can no longer rely solely on government funding, if it is to remain financially healthy. 
New styles and mechanisms of financial management are necessary. There are six key characteristics of the financially healthy University. These are (Akintayo, 2006):

- Short term solvency;

- Retention of reserves;

- The effective management of long term debt;

- The effective management of the estate;

- The stability to generate non-state funding;

- $\quad$ Consistency of budgetary strategy with mission.

Nevertheless, in spite of differences between various institutions and systems, I believe that there are six fundamental principles that must be observed. They are (Akintayo, 2006):

- Financial stability, which should make a key contribution to academic success;

- Financial management, which is too important to be left to the Bursar or Director of Finance alone;

- A conservative approach to institutional spending at the top, which should constantly send a message in favour of lean management of organizational resources, as well as transparency and accountability throughout the institution;

- That, risks should be examined carefully but, when accepted, the instrument should be sufficient to ensure a successful outcome;

- Good financial management requires that, where financial targets are not met, action should be taken immediately;

- Financial monitoring by policy makers, rather than technicians, can make a significant impact on the management of an institution.

It is necessary to state, at this juncture, that it is impossible to point to a 'right way' of managing University finance in general, because funding systems differ, and in particular, institutions differ. For example, managing the finances of a research university which has a significant grant income and major research facilities to maintain and, if it has a medical school, special relations with hospitals and state medical services or, if it has an agriculture or veterinary faculty, university farms to manage, are entirely different to managing the finances of a largely teaching university. This is not just a question of what the accounts of the two kinds of universities look like and the difference in the make-up of their income streams, but a matter of a different organization and structure.

It must be further noted that the most viable source of financing University education is the effective management of the university educational system and associated institutions. Consequently, this paper also isolates six critical factors that tend to influence new trends in the funding of universities. This can be done in the following ways (Obieumani, 2006):

- Rational allocation of cash funds;

- Management of cash reserves;

- Production of financial indicators;

- Better utilization of resources;

- Evaluation and auditing;

- Protection of funds from fraud.

In order to determine whether or not the finances of an organization are effectively managed, there is the need for financial reporting. The objective of financial reporting in the public sector, for example (where most universities in the developing countries are located), is to give a formal record of the financial activities and resources entrusted to it and provide information useful for decision making by (Edukugbo, 2008):

- Indicating whether resources were obtained and used in accordance with legally adopted budget;

- Indicating whether resources were obtained and used in accordance with legal and contractual requirements, including financial limits established by appropriate legislative authorities; 
- Providing information about the resources, allocation and uses of financial resources;

- Providing information about how the government or unit financed its activities and met its cash requirements;

- Providing information that is useful in evaluating governments or units' ability to finance its activities and to meet its liabilities and commitments;

- Providing information about financial condition of the government or unit and changes in it;

- Providing aggregate information useful in evaluating the governments or units performance in terms of service costs, efficiency and accomplishment.

\section{On the need for sustainable university administration and institution-building}

For a country, such as Nigeria, to get her quest for solid national development, there is the need to build sustainable and strong institutions. It must be noted at this juncture, that, if there has to be sustainable development in Nigerian universities, they have to be "adequately" funded. The financing of education should be the function of all the major stakeholders. This is because government alone cannot fund higher education. Inadequate funding of public universities has been identified as the prime cause of the problems of the universities (Ifakachukwu, 2009). There is need for strong institutions for service delivery, government efficiency, and strong policy and programme implementation. More importantly, there is the need to build capacity divorced from our individual, regional, religious and personal aggrandizement in order to encourage public and private sector sustenance.

It must be noted that, a country cannot grow or achieve much if she depends on individual genius, personality cult, and passion to run her public institutions.

The development of infrastructure, as well as maintenance and delivery of other state services need viable and functional institutions. These institutions should be the driving force towards the maintenance of the Country's dilapidated roads, outdated power infrastructure and other conceivable public sector services.

It may be pertinent to further state, at this juncture, that government agencies have failed because they failed to build an enduring institutional structure. If the government had built sustainable institution or leveraged on strategic capacity building, most of the critical challenges that are being encountered in the country could have been minimized.

Further still, on Nigeria, substantial investments of the nation's wealth should be made in favour of the training and retraining of the national workforce. This is because every nation's strength is in her work force. If an emerging nation such as Nigeria would develop a well-dedicated and trained work force, a substantial part of the nation's developmental problems could have been solved.

\section{Conclusion}

By and large the importance of effective university governance cannot be under- stated, given the primacy of strategic educational and knowledge management for the possible attainment of necessary economic growth and sustainable human development across the globe. The pursuit of the inclusive but multidimensional goals of sustainable university administration and strategic capacity building are also dependent on the extent to which institutional financial resources are prudently harnessed and managed.

Consequently, the university administration has a critical role to play in this nexus. Indeed, successful university administration in this $21^{\text {st }}$ century must leverage on the tenets of sound resources allocation, utilization and financial management to catalyze processes of necessary capacity building for balanced organization development and sustainable futures of the knowledge industry. 
In conclusion, the instrumentality of financial reporting, international best practices in strategic university administration and the necessary understanding of the harvestable pool of financial resources that is available to the global university system as well as various mechanisms for putting these into usage for the promotion of industrial peace and organizational stability in the university system are all necessary ingredients for managing university finances for sustainable administration and institution- building.

\section{References}

Abdu, P.S (2003) - "The Cost and Finance of Education in Nigeria" Education Today Quarterly; June, Vol. 10 (1); $12-16$

Akintayo, M.O. (2004) "Public Financing and the Problems of Access to University Education" in International J ournal of Literacy Education. June 2 (1 - 23).

Bloom, B.S. Stability and Change in Human Characteristics, New York: Wiley 1964.

Edukugbo, E. (2008). "How $=\mathrm{N}=832.6$ billion on education in 8 years declined in real terms". Vanguard Newspaper, Thursday, September 18, p.51.

Erinosho, L. (2004). "Challenges in higher Education in Nigeria", a Convocation Lecture delivered at the University of Ado-Ekiti by the Executive Secretary, Social Science Academy, The Guardian Friday J uly 2 p.46.

Federal Ministry of Education (2007). "Community Accountability and Transparency I nitiative for Universities", Abuja.

I shola, R.A. (2008). "Optimising Output from Tertiary Educational Institutions Via Adequate Funding: A Lesson from Nigeria" in International Research J ournal of Finance and Economics issue 14 (2008).

Obielumani, I. (2006). "Universal Basic Education (UBE) Workshop Requirements Projections for Ten years (2006 - 2015) in Delta State". J ournal of Education Research and Policies, 1 (1) p.86.

Vanguard Newspaper, Thursday, $5^{\text {th }}$ March, 2009, p.8.

UNESCO (1998) Higher Education in the Twenty first Century Vision and Actions, Paris UNESCO.

World Bank (2002) Constructing Knowledge Societies. New Challenges for Tertiary Education; Washington, World Bank. 